\title{
床座人体における伝導および相互反射放射を考慮した作用温度に関する研究 OPERATIVE TEMPERATURE CONSIDERING THE EFFECT OF HEAT CONDUCTION BETWEEN A HEATED FLOOR AND THE PERSON SITTING ON IT AND INTER-REFLECTION RADIATION
}

\author{
宮本征一*, 堀越哲美**, 崔 英 植***, 酒井克彦**** \\ Seiichi MIYAMOTO, Tetsumi HORIKOSHI, Choi Young SIK \\ and Katsuhiko SAKAI
}

\begin{abstract}
In order to indicate the effect of floor heating on the human body sitting on a floor it should be taken into account to estimate not only heat convection and radiation but also heat conduction between the human body and the floor. The objective of this paper is to introduce modified operative temperature to accomplish the above, and to verify the temperature using experimental data. Experiments were conducted in winter. Subjects were exposed to the following conditions : combinations of air temperature $20^{\circ} \mathrm{C}$, $22.5^{\circ} \mathrm{C}$ and $25^{\circ} \mathrm{C}$, and floor temperature $20^{\circ} \mathrm{C}, 22.5^{\circ} \mathrm{C}, 25^{\circ} \mathrm{C}, 27.5^{\circ} \mathrm{C}, 30^{\circ} \mathrm{C}, 32.5^{\circ} \mathrm{C}, 35^{\circ} \mathrm{C}, 37.5^{\circ} \mathrm{C}$ and $40^{\circ} \mathrm{C}$ under still air at $50 \%$ relative humidity. The modified operative temperature calculated from the experimental data was compared with the modified operative temperature by numerical calculation of heat conduction and radiation interchange. They were fairly agreed with each other.
\end{abstract}

Keywords: heat conduction, floor heating, operative temperature, human body, numerical calculation, experiment 熱伝導, 床暖房, 作用温度, 人体, 数値解析, 実験

1. はじめに

室内環境において、温熱環境指標として簡易に算出することがで きる作用温度 "が広く用いられている。この作用温度は、人体と 環境間の対流と放射による熱授受の関係から導き出された指標であ るため、伝導による熱授受は考慮されていない。立位または椅座位 であれば、床面と人体との接触面積は足裏のみであり、人体全体表 面に対する接触面の割合である接触面積比は小さい。そのため、伝 導による熱授受は、放射または対流による熱授受と比較し小さな值 となるため考慮されずに熱収支式が解かれ、PMV2)などの指標 が導き出されてきた。しかし、日本古来からの床座においては、慰 部と脚部が床面と接するため、立位や椅座位と比べ接触面積比が大 きくなり伝導による熱授受量が大きくなる。また、人体と床面との 距離が立位や椅座位と比べ短くなるため、放射による熱授受も大き く異なると考えられる。そのため、接触部の生理反応314)を明ら かにしていくとともに、人体と床との間の放射に加えて、床からの 伝導を考慮した温熱指標が必要となる。

そこで、本研究では人体と床面との間の形態係数および接触面積 比などの特性値を求める。そして、伝導を考虑した温熱環境指標で ある伝導修正作用温度を、熱授受の数値解析および被験者を用いた 実験に基づいて求め、比較検討を行うものである。

\section{2. 伝導修正作用温度の導出}

人体から環境への対流 $\mathrm{C}$ と放射 $\mathrm{R}$ による放熱量を次式であらわ し、作用温度 O T は、

$$
\begin{aligned}
& C+R \\
& =h_{c}\left(T_{S}-T_{a}\right)+h_{r}\left(T_{S}-T_{r}\right) \\
& =\left(h_{c}+h_{r}\right) T_{S}-\left(h_{c} T_{a}+h_{r} T_{r}\right) \\
& =\left(h_{c}+h_{r}\right)\left(T_{S}-\frac{h_{c} T_{a}+h_{r} T_{r}}{h_{c}+h_{r}}\right)
\end{aligned}
$$

$C:$ 対流による熱流量 $W / m^{2} \quad R$ : 放射による熱流量 $W / m^{2}$

$h_{C}$ : 対流熱伝達率 $W / \mathrm{m}^{20} \mathrm{C} \quad h_{r}$ : 放射熱妘達率 $W / \mathrm{m}^{20} \mathrm{C}$

$T_{\mathrm{a}}$ :気温 ${ }^{\circ} \mathrm{C} T_{r}$ : 平均放射温度 ${ }^{\circ} \mathrm{C} T_{s}$ : 平均皮虐温 ${ }^{\circ} \mathrm{C}$ と变形を行い、

$$
O T=\frac{h_{c} T_{a}+h_{r} T_{r}}{h_{c}+h_{r}}
$$

* 名古屋工業大学社全開発工学科 助手・博士 (工学)

** 名古屋工㞷業大学大学院都市循環システム工学尃攻 教授. 工博

*** 嶺南理厂大学建築科 教授

***** 株式会社日建設計名古屋事務所
Research Assoc., Dept. of Architecture, Faculty of Engineering, Nagoya Institute of Technology, Dr. Eng.

Prof., Dept. of Environment Technology and Urban Planning, Graduate School, Nagoya Institute of Technology, Dr. Eng.

Prof., Dept. of Architecture, Yeungnam College of Science \& Technology, Dr. Eng. Nikken Sekkei Ltd., Nagoya Office. 
と定義される ${ }^{\prime}$ 。この考え方を基に、対流、放射に加え伝導による 熱授受を考虑すると、平山ら により、

$$
\begin{aligned}
& C+R+C d \\
& =h_{c}\left(T_{S}-T_{a}\right)+h_{r}\left(T_{S}-T_{r}\right)+\frac{\lambda}{l}\left(T_{C S}-T_{C f}\right) f
\end{aligned}
$$

（d:伝導による熱流量 $W / m^{2} \quad \lambda$ :入体接触材の熱伝導率 $W / m^{\circ} \mathrm{C}$ I: 人体接触材の厚さ $m \quad T_{C S}$ : 接触部皮膚温 ${ }^{\circ} \mathrm{C} \quad T_{C r}$ : 接触部床温 ${ }^{\circ} \mathrm{C}$ $f:$ 全体表面積に対する接触面積の比 $\mathrm{m}^{2} / \mathrm{m}^{2}$

と記述することができ、接触部の熱コンダクタンス $\mathrm{h}_{\mathrm{d}}$ を、

$$
h_{d}=\frac{\lambda}{l} \frac{\left(T_{C S}-T_{C f}\right)}{\left(T_{S}-T_{f}\right)} f
$$

とすると、

$$
\begin{aligned}
& =h_{c}\left(T_{S}-T_{a}\right)+h_{r}\left(T_{S}-T_{r}\right)+h_{d}\left(T_{S}-T_{f}\right) \\
& =\left(h_{c}+h_{r}+h_{d}\right) T_{S}-\left(h_{c} T_{a}+h_{r} T_{r}+h_{d} T_{f}\right) \\
& =\left(h_{c}+h_{r}+h_{d}\right)\left(T_{S}-\frac{h_{c} T_{a}+h_{r} T_{r}+h_{d} T_{f}}{h_{c}+h_{r}+h_{d}}\right)
\end{aligned}
$$

となり、伝導修正作用温度 $\mathrm{O} T$ ，を字式のように定義できる。

$$
O T_{f}=\frac{h_{c} T_{a}+h_{r} T_{r}+h_{d} T_{f}}{h_{c}+h_{r}+h_{d}}
$$

となる。ここで、接触部床温が未知数である。そのため、非定常熱 伝導方程式を、二物体の接触問題に対する井上の解法 ${ }^{6}$ (《甘11を用 い、初期条件は一次関数の温度分布、境界条件は熱流が等しいとし て解く。解かれた方程式は、

$$
\begin{gathered}
T_{c f}=\frac{b_{1} T_{f}+b_{2} T_{S}}{b_{1}+b_{2}}+\frac{2\left(H_{1}-H_{2}\right) \sqrt{t}}{\left(b_{1}+b_{2}\right) \sqrt{\pi}} \\
H_{1}=h_{c f}\left(T_{f}-T_{a}\right) \\
H_{2}=h_{c s}\left(T_{S}-T_{a}\right)
\end{gathered}
$$

$b_{1}:$ 人体接触材の熱浸透率 $W / m^{20} \mathrm{C} \cdot h^{0.5}$

$b_{2}$ : 人体の熱浸透率 $W / m^{2}{ }^{2} \mathrm{C} \cdot h^{0.5} \quad l$ : 経過時間 $h$

\begin{tabular}{|c|c|c|c|c|c|}
\hline $\begin{array}{l}\text { 気温 } \\
{ }^{\circ} \mathrm{C}\end{array}$ & $\begin{array}{l}\text { 床温 } \\
{ }^{\circ} \mathrm{C}\end{array}$ & $\begin{array}{c}\text { 相対湿度 } \\
\%\end{array}$ & $\begin{array}{l}\text { 気流 } \\
\mathrm{m} / \mathrm{s}\end{array}$ & $\begin{array}{l}\text { 壁温 } \\
{ }^{\circ} \mathrm{C}\end{array}$ & 被験者 \\
\hline \multirow{7}{*}{20.0} & 2.0 .0 & \multirow{20}{*}{50} & \multirow{20}{*}{$V \leqq 0.1$} & \multirow{20}{*}{ =気温 } & MN YN HM SG \\
\hline & 27.5 & & & & $\mathrm{SM}$ \\
\hline & 30.0 & & & & MN YN HM SG \\
\hline & 32.5 & & & & MK TF \\
\hline & 35.0 & & & & MN YN HM SG \\
\hline & 37.5 & & & & TF SM \\
\hline & 40.0 & & & & SM MK YI \\
\hline \multirow{7}{*}{22.5} & 22.5 & & & & MN YN HM SG \\
\hline & 27.5 & & & & TF \\
\hline & 30.0 & & & & MN YN HM SG \\
\hline & 32.5 & & & & MK SM \\
\hline & 35.0 & & & & MN YN HM SG \\
\hline & 37.5 & & & & MK YT \\
\hline & 40.0 & & & & TF YT CW \\
\hline \multirow{6}{*}{25.0} & 25.0 & & & & KT MA YM TU SU YI \\
\hline & 30.0 & & & & KT MA TM TU SU YI \\
\hline & 32.5 & & & & SM YT \\
\hline & 35.0 & & & & KT MA TM TU \\
\hline & 37.5 & & & & TF YT \\
\hline & 40.0 & & & & MK CW YT \\
\hline
\end{tabular}

$H_{1}$ : 床面接触部の熱流量 $\mathrm{W} / \mathrm{m}^{2} \quad \mathrm{H}_{2}$ : 人体接触部の熱流量 $\mathrm{W} / \mathrm{m}^{2}$

$h_{c f}$ : 休面の対流熱伝達率 $W / \mathrm{m}^{2}{ }^{\circ} \mathrm{C} \quad h_{c s}$ : 人体の対流熱伝達率 $W / m^{2}{ }^{\circ} \mathrm{C}$

\begin{tabular}{|c|c|c|c|c|c|c|}
\hline 被験者 & $\begin{array}{l}\text { 身長 } \\
\mathrm{cm}\end{array}$ & $\begin{array}{c}\text { 体重 } \\
\mathrm{kg}\end{array}$ & $\begin{array}{c}\text { 全体表面積 } \\
\mathrm{m}^{2}\end{array}$ & $\begin{array}{c}\left.\text { 接触面積 }{ }^{*}\right) \\
\mathrm{m}^{2}\end{array}$ & 年齢 & 出身地 \\
\hline $\mathrm{KT}$ & 166.2 & 65.1 & 1.69 & 0.059 & 21 & 愛知 \\
\hline MA & 172.2 & 53.6 & 1.58 & 0.061 & 21 & 愛知 \\
\hline TU & 168.2 & 73 & 1.78 & 0.078 & 21 & 静岡 \\
\hline SU & 171.1 & 62.7 & 1.69 & 0.074 & 21 & 愛知 \\
\hline $\mathrm{MN}$ & 174.6 & 69.5 & 1.79 & 0.083 & 21 & 愛知 \\
\hline $\mathrm{YN}$ & 168.0 & 55.6 & 1.58 & 0.062 & 21 & 和歌山 \\
\hline MK & 167.0 & 61.8 & 1.65 & 0.075 & 21 & 岐阜 \\
\hline TF & 168.0 & 64.8 & 1.69 & 0.085 & 23 & 富山 \\
\hline YT & 166.0 & 69.2 & 1.73 & 0.076 & 21 & 愛知 \\
\hline SM & 175.0 & 60.4 & 1.68 & 0.076 & 22 & 岐阜 \\
\hline TM & 166.1 & 55.9 & 1.57 & 0.065 & 21 & 愛知 \\
\hline
\end{tabular}
となる。

\section{3. 伝導修正作用温度による評価}

3-1 生理・心理反応実験による伝導修正作用温度の算出

床暖房などが行われている環境下において: 床座など床面と

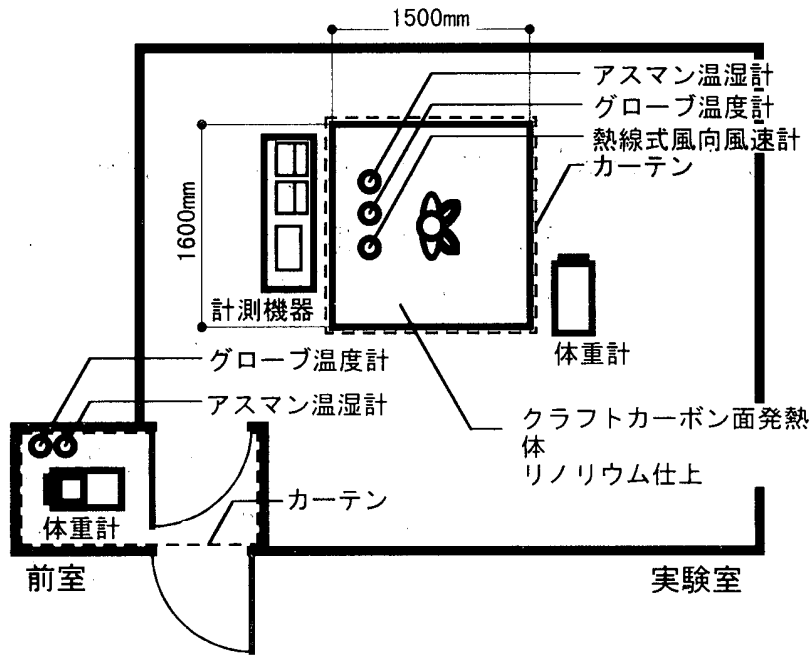

図 1 恒温室の平面図

表 1, 生理・心理反応実験の設定条件

表 2 生理・心理反応実験の被験者身体データ

*) DuBois-Area $=0.007184 \mathrm{~W}^{0.425} \mathrm{H}^{0.725}$ W: 体重 $\mathrm{kg} \mathrm{H}$ : 身長 $\mathrm{cm}$ 
接する面積が大きな場合には、伝導による熱授受を考慮しなければ ならないと考えられる。そこで、1991 年と1992 年の冬季に、被験 者を用いた生理・心理反応の日本人に対する赛験データ ${ }^{7)}$ から伝 導修正作用温度を算定する。実験は、図 1 に示寸ように名古屋工業 大学にある恒温室内に周囲をカーテンで囲ったブースを作成し行っ

た。実験の設定条件は、表 1 に示す気温と床温との組み合わせとし た。被験者はトランクスのみの裸体で、胡座姿勢で床面中央に位置 した。被験者の身体データを表 2 に示す。人体と床面との接触面積 は感光紙を用いて測定した後、デジタイザーを用いて求めた。床面 は、木材床面上に断熱材を敷き、クラフトカーボン面発熱体を置き、 リノリウム仕上げである。皮膚温は、0.2 mm $\phi$ の T 型熱電対を用い て Hardy-DuBois の 12 部位 ${ }^{8)}$ から大腿後、下腿後を除く部位およ び床面と人体との接触面である腎部、足側と足底、手掌において測 定した。表 3 の重み係数を用いて伝導修正平均皮膚温を算出した。 皮膚表面熱流は、熱電堆式熱流計を用いて Hardy-DuBois の 12 部 位から大腿後、下腿後、足背を除く部位および腎部、足側において 測定した。

\section{3-2 数值解析による伝導修正作用温度の算出}

対流による熱授受に関しては、胡座位姿勢における自然対流域

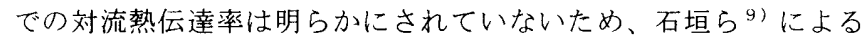
椅座位姿勢における自然対流域での対流熱伝達率を用いた。

放射による熱授受に関しては、より正確な数值解析を行うため に、立体角投射法則に基づいた写真法 ${ }^{10)}$ を用いて、人体と空間構 成面との間の形態係数を測定した。被験者を空間中央の床に位置さ せ、被験者から $1 \mathrm{~m}$ または $2 \mathrm{~m}$ 離れた距離にある空間構成面上の $50 \mathrm{~cm} \times 50 \mathrm{~cm}$ の格子点より測定を行った。表 4 に示す青年男子 3 名 （被験者 $\mathrm{KW}$ 、被験者 S S、被験者 O T ）の被験者を用い、被験者 の姿勢は胡座とし着衣はトランクスのみの裸体とした。姿勢を胡座 としたため、立位や椅座位と比べ床面と人体との間の距離が短くな り、人体近傍において形態倸数は急激に変化する。そのため、表 4 に示寸青年男子 3 名（(被験者 $\mathrm{KW}$ 、被験者 S S、被験者 $\mathrm{AN}$ ) の 被験者を用い、従来の方法より細かい $12 \mathrm{~cm} \times 12 \mathrm{~cm}$ の格子上の点よ り測定した。また、人体と床面との接触面積は感光紙を用いて測定 した。測定された人体データを用い、図 2 に示すような人体による 遮蔽を考慮した各面から各面への形態係数 11 を求め、相互反射を 考虑した Net Radiation 法を、空間構成面および人体面に抁張し用 いて、平均放射温度の算出 $\left.{ }^{2} 2\right)$ を行った。算出に用いた放射率につ いては、空間構成面は 0.95 、人体表面は 0.98 とした。

伝導による熱授受に関しては、被験者を用いた生理・心理反忘 実験に用いた床材を考慮して、床材の熱浸透率・熱伝導率は、リノ リウムの熱浸透率 $9.9 \mathrm{~W} / \mathrm{m}^{2}{ }^{\circ} \mathrm{C} \cdot \mathrm{h} /$ ' と熱伝導率 $0.15 \mathrm{~W} / \mathrm{n}^{\circ} \mathrm{C}$ を用い、 床材の厚さは、被験者実験に用いた装置の值である $1 \mathrm{~cm}$ とした。 人体の熱浸透率は、16.7 W/m ${ }^{20} \mathrm{C} \cdot \mathrm{h}^{(2,26)}$ とした。接触部床温算出に 必要な休面の対流熱伝達率は、水平面の面加熱における自然対流域 での対流熱伝達率13) を用いた。また、人体の対流熱伝達率は、石 垣らによる椅座位姿勢における自然対流域での対流熱伝達率を用い た。被験者実験の曝露時間を 60 分としたため、経過時間は 60 分と した。
表 3 床温との接触を考慮した平均皮虚温算出の重み係数

\begin{tabular}{|c|c|c|}
\hline & & 平均皮膚温算出の重み係数 \% \\
\hline 頭部 & 前額 & 7 \\
\hline \multirow{4}{*}{ 躯幹 } & 胸乳 & 8.75 \\
\hline & 臍 & 8.75 \\
\hline & 肩甲棘 & 8.75 \\
\hline & 腸骨櫛 & 8.75 \\
\hline \multirow{3}{*}{ 上肢 } & 前腕 & 14 \\
\hline & 手背 & 2.5 \\
\hline & 手掌 & 2.5 \\
\hline \multirow{8}{*}{ 下肢 } & 大腿前 & 9.5 \\
\hline & 大腿後 & $9.5-S_{1}$ \\
\hline & 臂部 & $S_{1}$ \\
\hline & 下腿前 & \multirow{2}{*}{13} \\
\hline & 下腿後 & \\
\hline & 足背 & 3.5 \\
\hline & 足底 & $3.5-S_{2}$ \\
\hline & 足側 & $\mathrm{S}_{2}$ \\
\hline
\end{tabular}

表 4 形態係数測定の被験者身体データ

\begin{tabular}{|c|c|c|c|c|c|}
\hline 被験者 & $\begin{array}{l}\text { 身長 } \\
\mathrm{cm}\end{array}$ & $\begin{array}{c}\text { 体重 } \\
\mathrm{kg}\end{array}$ & $\begin{array}{c}\text { 全体表面積 }{ }^{*)} \\
\mathrm{m}^{2}\end{array}$ & $\begin{array}{c}\text { 有効放射面積 } \\
\mathrm{m}^{2}\end{array}$ & 年撂 \\
\hline $\mathrm{KW}$ & 168.0 & 65.0 & 1.74 & 1.11 & 21 \\
\hline SS & 173.3 & 65.5 & 1.78 & 1.21 & 21 \\
\hline OT & 177.6 & 78.2 & 1.96 & 1.17 & 21 \\
\hline AN & 167.0 & 55.0 & 1.61 & -- & 21 \\
\hline
\end{tabular}

*) DuBois-Area $=0.007184 \mathrm{~W}^{0.425} \mathrm{H}^{0.725}$

W: 体重kg $\mathrm{H}$ : 身長cm

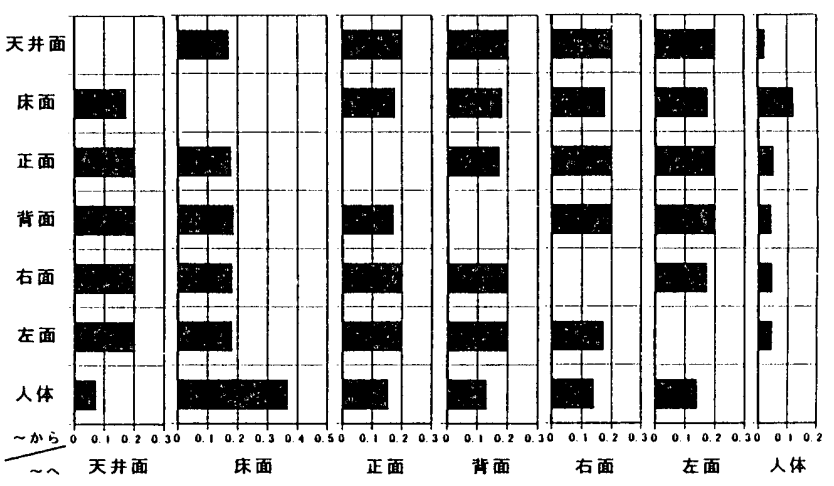

図 2 人体による遮蔽を考慮した形態係数 $(2 \mathrm{~m} \times 2 \mathrm{~m} \times 2 \mathrm{~m}$ 空間 $)$

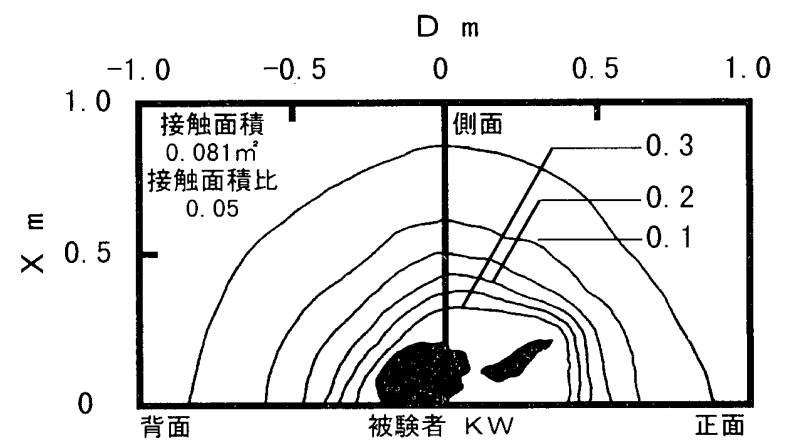

図 3 床面から人体への形態係数および接触面積（被験者 $\mathrm{KW}$ ) 
4. 結果

床面から人体への形態係数および接触部面積、接触部面積比を 図3 から図 5 に示す。

被験者実験により求められた伝導修正皮膚温と伝導修正作用温 度との関係を図 6 に示す。

数值解析により、気温が $17.5^{\circ} \mathrm{C} 、 20.0^{\circ} \mathrm{C} 、 22.5^{\circ} \mathrm{C} 、 25.0^{\circ} \mathrm{C} 、 27.5^{\circ} \mathrm{C} 、$ $30.0^{\circ} \mathrm{C}$ で、床温が $20^{\circ} \mathrm{C}$ から $40^{\circ} \mathrm{C}$ の間である環境に対して、平均放 射温度、接触部床温、伝䆃修正作用温度を算出した。ただし、人体 に関係する係数は、表 2 に示した被験者の全体表面積の平均犆 1.71 $\mathrm{m}^{2}$ と接触面積の平均値 $0.074 \mathrm{~m}^{2}$ から全体表面積に対する接触面積の 比 0.043 を求めた。また、有効放射面積率は 0.64 とし、人体表面 温度は $33^{\circ} \mathrm{C}$ とた。気温と床温との組み合わせと平均放射温度と の関係を図 7 に、接触部床温との関倸を図 8 に、伝導修正作用温度 との関係を図 9 に示す。

\section{5. 考察}

接触部の形状および放射授受量に影響を与える形態係数を、図 3 から図 5 までを用いて考察する。形態係数の值は、体の周り $50 \mathrm{~cm}$ の距離で 0.1 程度であり、人体の周り $5 \mathrm{~cm}$ の距離で 0.3 程度である。 人体近傍 $10 \mathrm{~cm}$ 程度の距離から急激に変化している。床面から人体 への形態係数は、局部的には個人差が見られるものの、形態係数の 分布の形状に関して個人差はあまり見られない。接触面積の形状は、 大腿後上部に多少の個人差がみられ、大腿後上部が接触している被 験者ほど接触面積率が大きくなる傾向がみられる。

図 6 より、床暖房を行っている環境の評価を考察する。伝導修 正作用温度と伝導修正平均皮膚温との関係は、伝導を考慮している ため作用温度、平均皮虐温はよく対応し、相関が高く相関係数は 0.84である。この伝導修正作用温度および伝導修正平均皮膚温は、 伝導による熱授受が存在する環境を評価する指標として有効である と考えられる。

図 7 より、被験者を用いた生理・心理実験と比較検討するため に、壁面の放射率 0.95 として算出したため、相互反射の影響はあ まりみられず、床温とともに平均放射温度は線形的に上昇した。

図 8 より、接触部床温は、気温により多少の違いがみられるも のの、床温 $20^{\circ} \mathrm{C}$ で接触部床温 $27^{\circ} \mathrm{C}$ 、床温 $26^{\circ} \mathrm{C}$ で接触部床温 $30^{\circ} \mathrm{C}$ 、 床温 $40^{\circ} \mathrm{C}$ で接触部床温 $38^{\circ} \mathrm{C}$ である。人体表面を $33^{\circ} \mathrm{C}$ とて数值解 析を行ったため、 $33^{\circ} \mathrm{C} よ り$ 低い床温では人体から床面に熱流が流れ、 $33^{\circ} \mathrm{C}$ 上り高い床温では床面から人体に熱流が流れるように逆転する ため、このような值が算出されたと考えられる。

図 9 より、数值解析により算出された伝導修正作用温度は、床 温 $32^{\circ} \mathrm{C}$ 放 $34^{\circ} \mathrm{C}$ の閒において非線形的な举動を示す。これは、上 述のように人体の表面温度を $33^{\circ} \mathrm{C} に$ 固定し数值解析を行ったため、 床温が限りなく $33^{\circ} \mathrm{C} に$ 近付くと人体の表面温度と接触部床温との 差が小さくなり、数㣨計算上の誤差が生じているものであると考え られる。それ以外においては、ほぼ線形的な関倸であり、床温を $5{ }^{\circ} \mathrm{C}$ 変化させると伝䆃修正作用温度は $1{ }^{\circ} \mathrm{C}$ 変化する。

実験により求められた伝導修正作用温度と数值解析により求め られた伝導修正作用温度を、同じ図上にプロットし図 10 に示す。 ただし、実験において気温を一定にするように床温などの制御を行 うのは困難なため気温が $20^{\circ} \mathrm{C} \pm 1.25^{\circ} \mathrm{C} 、 22.5^{\circ} \mathrm{C} \pm 1.25^{\circ} \mathrm{C}$ 、

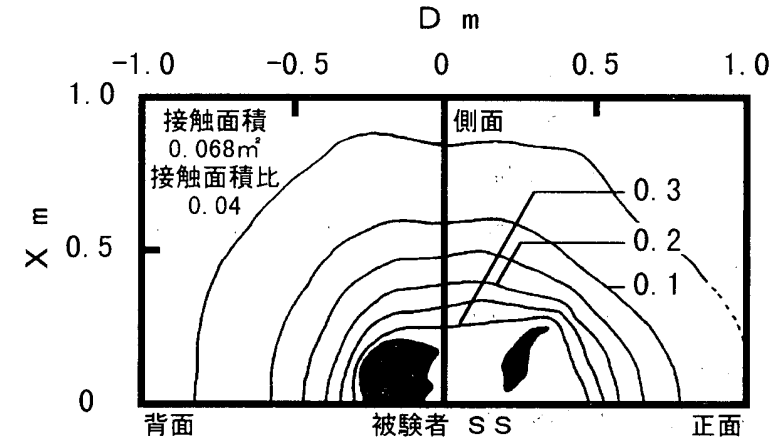

図 4 床面から人体への形態係数および接触面積（被験者 S S )

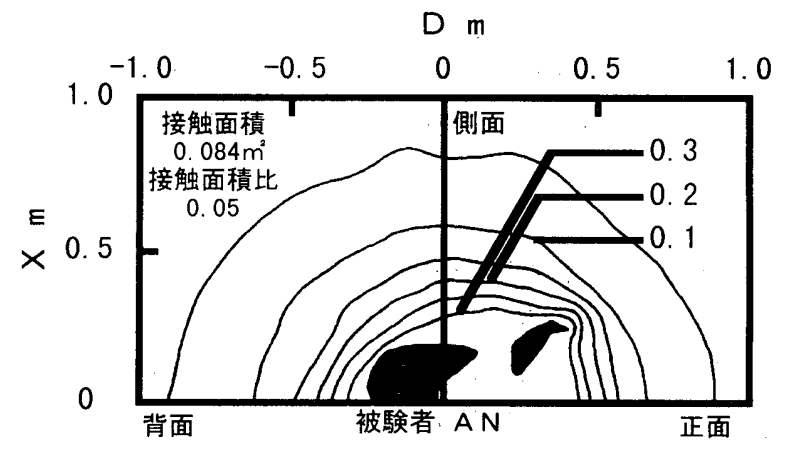

図 5 床面から人体への形態係数および接触面積（被駚者AN）

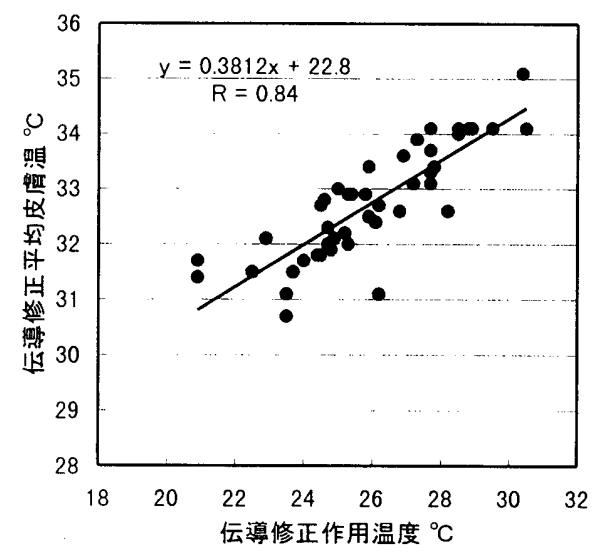

図 6 実験による伝導修正皮膚温と伝導修正作用温度との関係

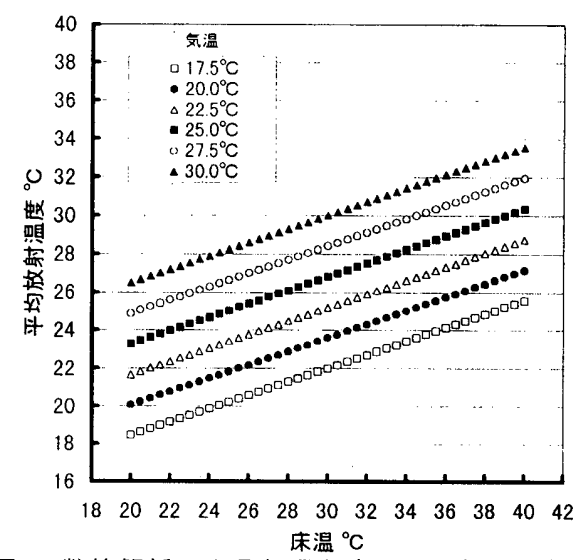

図 7 数值解析による気温と床温との組み合わせと 平均放射温度との関係 
$25^{\circ} \mathrm{C} \pm 1.25^{\circ} \mathrm{C} 、 27.5^{\circ} \mathrm{C} \pm 1.25^{\circ} \mathrm{C}$ あ゙あるものをそれぞれのグループと し、プロットをした。

実験と数值解析により求められた伝導修正作用温度を比べてみ ると、床温が低い場合（実験の設定条件で床温と気温が等しい場合） においては、実験結果は数値解析の結果とほぼ一致している。床温 が気温より高い場合においては、数值解析の結果と実験の結果に多 少のばらつきがあるものの、数值解析と実験の結果は同様な傾向を 示している。従って、数値解析による伝導を考慮した温熱指標であ る伝導修正作用温度の推定はほぼ妥当であると考えられる。

\section{6. 結論}

床暖房など伝導による熱授受を考慮しなければならない環境の温 熱指標として、作用温度を拡張した伝導修正作用温度を求めた。伝 導修正作用温度を算出する際に必要となる人体と各面との形態倸数、 人体有効放射面積や床面との接触面積を求めた。

また、被験者実験により求められた伝導修正作用温度は、平均 皮膚温とよく対応寸る。実験と数值解析で求められた伝導修正作用 温度とを比較した。皮膚温と床温との差が小さい場合には、数值計 算の若干の誤差が出るが、実験により求められた伝導修正作用温度 と同様な傾向を示すことを明らかにした。

このことにより、伝導修正作用温度は数值解析により予測可能 であると考えられる。人体の生理・心理反応との関係については、 今後報告する予定である。

引用文献

1) C,-E. A. Winslow, L. P. Herrington, A. P. Gagge: Physiological reactions of the human hody to varying environmental temperatures, The American Journal of Physiology Vol. 120, No. 1, September, 1937 2) Fanger P. 0.: Thermal Comfort, Danish Technical Press, 1970 3）永村一雄、斎藤平蔵：休暖房と人体生理抢よび温洽感との関係に関する 実験的基礎研究、日本建築学会論文報告集、第353号、pp. 21-31、1985 4) Kim, B., Isoda, I. and Yanase, T. : Influence of floor heating lemperature on the human hody seated on the floor, 日本建築学会論文 報告集、第 417 号、pp. 19-29、1990

5 ）平山慶太郎、堀越哲美、蔵澄美仁、土川忠浩、本間宏、小林陽太郎：床 温と気温が人体に及ぼ寸影響の実験 その2，夏季、椅座安静、着衣、青年 男子り場合、日本建築学会東海支部研究報告集第 23 号、pp. 213-216、1985 6) 井上和夫：温熱環境条件としてい床温の人体影響に関するる実験的研究、 東京工業大学大学院修士論文、1997

7) 崔英植、堀越哲美、宮本征一、水谷章夫：床暖房時ひ気温と床温が胡座 人体に及代子影響に関子万研究、日本建築学会論文報告集、第 480 号、pp.7-1 小、 1996

8) Hardy, J. D. \& DuBois, E.F.: The Technic of Measuring Radiation and Convection, Journal of Nutrition Vol. 15 No. 5, pp. 461-475, 1938

9 ) 石垣：人体の対流熱伝達率に関する実験的研究、名古屋工業大学修士論 文、1990

10）堀越哲美、小林陽太郎：人体と矩形面とり間り形態係数および人体ふく 射面積に関卞方研究 1. 算出理論と椅座着衣り場合り実測、日本建築学会 論文報告集、第268 号、pp. 109-120、1978

11）宮本征一、土川忠浩、堀越哲美、水谷章夫：床座時の人体に上る遮蔽を 考慮した空間構成面間り形態係数に関扵る研究、日本建築学会諭文報告集、 第 497 号、pp. 33-38、1997

12）宮本征一 堀越哲美士川忠浩：相互反射及び人体による遮蔽を考慮した 平均放射温度に関才万研究、日本建築学会計画系論文集、第 498 号、pp. 45 $-49,1997$

13) 1993 ASHRAE HANDBOOK FLNDAMINTALS SI Edition, 3.12

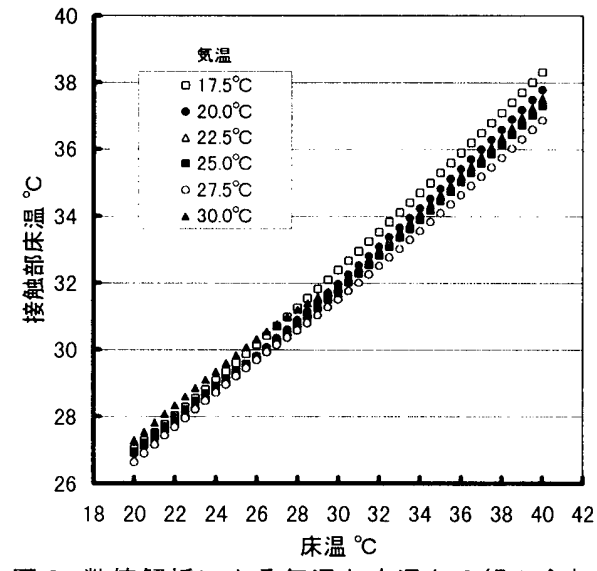

図 8 数值解析による気温と床温との組み合わせと

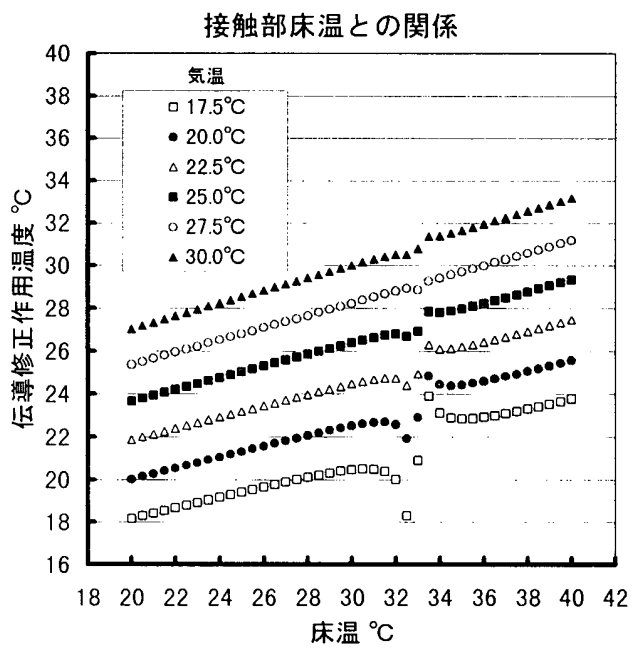

図 9 数值解析による気温と床温との組み合わせと 伝導修正作用温度との関係

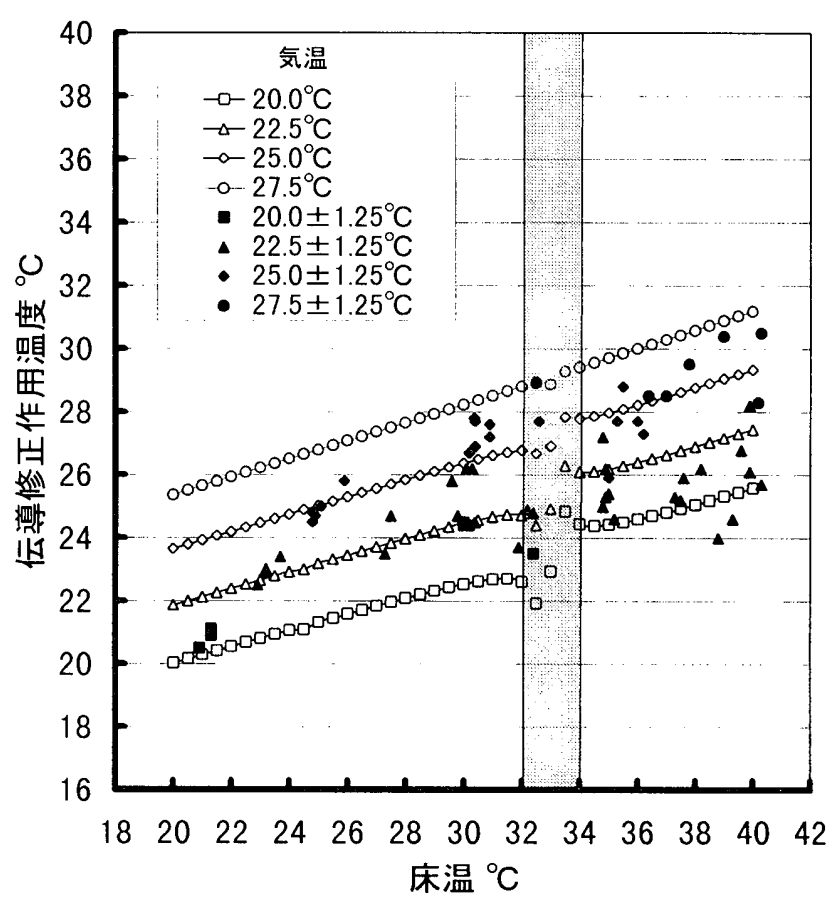

図 10 実験および数値解析により求められた伝導修正作用温度 
【注 1】

半無限壁体と半無限壁体の接触の基礎式は、（式1）と（式2）の上うに 表せられる

$$
\frac{\partial T_{1}}{\partial t}=a_{1} \frac{\partial^{2} T_{1}}{\partial x^{2}} \quad \ldots \text { (式 1) } \quad \frac{\partial T_{2}}{\partial t}=a_{2} \frac{\partial^{2} T_{2}}{\partial x^{2}} \quad \ldots \text { (式 2) }
$$

但し $\mathrm{T}$ ：壁体ひ温度 $\mathrm{t}$ ：時間 $\mathrm{x}$ : 接触面と直角方向ひ距離

$$
\mathrm{a} \text { : 温度伝播率 }(=\lambda / \mathrm{e} \rho)
$$

ここで、(式1) と（式2）を解く際に、無限固体として扱い、仮想部分 老適宜に定め、以下ひ初期条件と接触条件を用いる

$$
\begin{aligned}
& \text { 初期条件 }(\mathrm{t}=0 \text { ) 時) } \\
& T_{1}=f_{1}(x)=u_{1}+v_{1} x \quad(x<0) \\
& =u_{1}^{\prime}+v_{1}^{\prime} x \quad(x>0) \quad \cdots \text { (式:3) } \\
& T_{2}=f_{2}(x)=u_{2}+v_{2} x \quad(x<0) \\
& =u_{2}{ }^{\prime}+v_{2}^{\prime}{ }^{\prime} \quad(x>0) \quad \ldots(\text { 式 } 4)
\end{aligned}
$$

\section{接触条件}

$$
\left(T_{1}\right)_{x=0}=\left(T_{2}\right)_{x=0}
$$

$$
\lambda_{1}\left(\frac{\partial T_{1}}{\partial x}\right)_{x=0}=\lambda_{2}\left(\frac{\partial T_{2}}{\partial x}\right)_{x=0}
$$

但し $u$ : 接触面温度 $(\mathrm{t}=0) \quad \mathrm{v}$ : 温度勾配 $(\mathrm{l}=0)$

$$
\lambda: \text { 熱伀䆃率 }
$$

初期条件（式 3）が与えられている時の無限固体（式 1）の解は、（式 7) である。

$$
T_{1}=\frac{1}{2 \sqrt{a_{1} t \pi}} \int_{-\infty}^{\infty} f_{1}(\lambda) e^{-(x-\lambda)^{2}} 4 a_{1} t \quad d \lambda \quad \cdots \text { (式 7) }
$$

（式3）を代入し解き、接触部 $(x=0)$ では、（式 8 ）(式9）となる

$\left(T_{1}\right)_{x=0}=\frac{u_{1}+u_{1}^{\prime}}{2}+\frac{\left(v_{1}^{\prime}-v_{1}\right) \sqrt{a_{1} t}}{\sqrt{\pi}} \cdots($ 式 8)

$$
\left(\frac{\partial T_{1}}{\partial x}\right)_{x=0}=\frac{v_{1}+v_{1}^{\prime}}{2}-\frac{\left(u_{1}-u_{1}^{\prime}\right)}{2 \sqrt{a_{1} t \pi}}
$$

同様に、（式１０）（式１１）が成り立つ

$$
\begin{aligned}
& \left.\left(T_{2}\right)_{x=0}=\frac{u_{2}+u_{2}^{\prime}}{2}+\frac{\left(v_{2}^{\prime}-v_{2}\right) \sqrt{a_{2} t}}{\sqrt{\pi}} \cdots \text { (式 } 10\right) \\
& \left(\frac{\partial T_{2}}{\partial x}\right)_{x=0}=\frac{v_{2}+v_{2}^{\prime}}{2}-\frac{\left(u_{2}-u_{2}^{\prime}\right)}{2 \sqrt{a_{2} t \pi}} \quad \cdots(\text { 式 } 11)
\end{aligned}
$$

（式 5) と（式6）の接触条件に（式 8) 〜（式11）を代入し、時間に

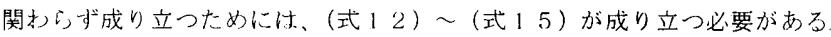

$$
\begin{array}{ll}
u_{1}+u_{1}^{\prime}=u_{2}+u_{2}{ }^{\prime} & \cdots \text { (式 1 2) } \\
\sqrt{a_{1}}\left(v_{1}^{\prime}-v_{1}\right)=\sqrt{a_{2}}\left(v_{2}^{\prime}-v_{2}\right) & \cdots \text { (式 } 13 \text { ) } \\
\lambda_{1}\left(v_{1}+v_{1}^{\prime}\right)=\lambda_{2}\left(v_{2}+v_{2}^{\prime}\right) & \cdots \text { (式 1 } 4 \text { ) } \\
\frac{\lambda_{1}}{\sqrt{a_{1}}}\left(u_{1}+u_{1}^{\prime}\right)=\frac{\lambda_{2}}{\sqrt{a_{2}}}\left(u_{2}+u_{2}^{\prime}\right) & \cdots \text { (式 } 15 \text { ) }
\end{array}
$$

(式12）〜（式１5）より、

$$
\begin{aligned}
& \frac{1}{2}\left(u_{1}+u_{1}^{\prime}\right)=\frac{\frac{\lambda_{1}}{\sqrt{a_{1}}} u_{1}+\frac{\lambda_{2}}{\sqrt{a_{2}}} u_{2}^{\prime}}{\frac{\lambda_{1}}{\sqrt{a_{1}}+\frac{\lambda_{2}}{\sqrt{a_{2}}}}}=\frac{b_{1} u_{1}+b_{2} u_{2}^{\prime}}{b_{1}+b_{2}} \quad \cdots(\text { 式 } 16 \text { ) } \\
& \sqrt{a_{1}}\left(v_{1}^{\prime}-v_{1}\right)=\sqrt{a_{1}} \frac{2\left(-\frac{\lambda_{1}}{\sqrt{a_{1}}} v_{1}+\frac{\lambda_{2}}{\sqrt{a_{1}}} v_{2}^{\prime}\right)}{\frac{\lambda_{1}}{\sqrt{a_{1}}}+\frac{\lambda_{2}}{\sqrt{a_{2}}}}=\frac{2\left(-\lambda_{1} v_{1}+\lambda_{2} v_{2}^{\prime}\right)}{b_{1}+b_{2}} \\
& \text { ここで } \\
& b=\frac{\lambda}{\sqrt{a}}=\frac{\lambda}{\sqrt{\lambda / c \rho}}=\sqrt{\lambda c \rho} \text { 熱浸透率 }
\end{aligned}
$$

（式16）と（式７）を（式 8）に代入すると、

$\left(T_{1}\right)_{x=0}=\frac{b_{1} u_{1}+b_{2} u_{2}^{\prime}}{b_{1}+b_{2}}+\frac{2\left(-\lambda_{1} v_{1}+\lambda_{2} v_{2}^{\prime}\right)}{b_{1}+b_{2}} \frac{\sqrt{t}}{\sqrt{\pi}} \quad \cdots \quad($ 式 18 )

ここで、 $\lambda v=H \quad(H$ : 熱流量) であるため、以下の式となる。

$$
\left(T_{1}\right)_{x=0}=\frac{b_{1} u_{1}+b_{2} u_{2}^{\prime}}{b_{1}+b_{2}}+\frac{2\left(-H_{1}+H_{2}\right)}{b_{1}+b_{2}} \frac{\sqrt{t}}{\sqrt{\pi}}
$$

